Г. О. Глазкова

\title{
СИСТЕМА ВПРАВ У ФОРМУВАННІ ФОНОСТИЛІСТИЧНИХ УМІНЬ І НАВИЧОК УЧНІВ ПРОФІЛЬНИХ КЛАСІВ
}

\footnotetext{
Глазкова Г. О. Система вправ у формуванні фоностилістичних умінь і навичок учнів профільних класів.

У статті 3'ясовано поняття «фоностилістичні уміння і навички» учнів профільних класів; розглянуто систему вправ для ефективного формування фоностилістичних умінь і навичок.

Ключові слова: фоностилістичні уміння і навички, класифікація вправ, стилістичне редагування, фоностилістичні засоби.
}

Глазкова А. А. Система упражнений в формировании фоностилистических умений и навыков учеников профильных классов.

В статье определены понятия фоностилистических умений и навыков учеников профильных классов; рассмотрена система упражнений для эффективного формирования фоностилистических умений и навыков.

Ключевые слова: фоностилистические умения и навыки, классификация упражнений, стилистическое редактирование, фоностилистические средства.

Glazkova G. O. The system of exercises in forming the phonostylistic skills of students in senior grades.

The article deals with the notion of phonostylistic skills of students in senior grades; the system of exercises for effective forming of the phonostylistic skills is considered by the author.

Key words: phonostylistic skills, classification of exercises, stylistic editing, phonostylistic means.

Навчання стилістики української мови останнім часом характеризується посиленням наукового інтересу до функціональногостилістичних особливостей звукового оформлення мовлення, проте в методиці чітко не визначено поняття «фоностилістичні уміння і навички».

Сучасна психологія для позначення інструментальної основи послуговується терміном «компетентність», який розкривається через такі важливі поняття, як «знання» (не лише сукупність відомостей про навколишній світ, а й здатність орієнтуватися в системі соціальних взаємин, діяти відповідно до обставин у різних життєвих ситуаціях), «уміння» (здатність людини усвідомлено застосовувати набуті знання адекватно новим обставинам діяльності) i «навички» (опанування до

(ㄷ..О.Глазкова, 2011. 
автоматизму способами використання певних засобів діяльності). Через названі поняття розкривається зміст програм із рідної мови та перевіряється успішність навчання. Тож проаналізувавши методичну літературу 3 питання формування фонетичних i стилістичних умінь $\mathrm{i}$ навичок, пропонуємо на їі основі виокремити фоностилістичні уміння $\boldsymbol{m a} \boldsymbol{н а в и ч к и , ~ я к і ~ п е р е д б а ч а ю т ь ~ р о з р і з н ю в а н н я ~ с т и л і в , ~ в и з н а ч е н н я ~ о с н о в н и х ~}$ їхніх ознак (характерні особливості на фонетичному рівні, такі, як інтонація, наголошеність / ненаголошеність голосних, наявність / відсутність стилістично маркованих фонетичних одиниць); послуговування тим чи тим стилем під час продукування мовлення (уміти створювати звуковий ефект, звукообрази за допомогою фоностилістичних засобів); удосконалення стилю сказаного і написаного (стилістично доцільно замінювати, дотримуватися правил евфонії, чергування $\boldsymbol{b} / \boldsymbol{y}, \boldsymbol{i} / \check{\boldsymbol{u}}$,

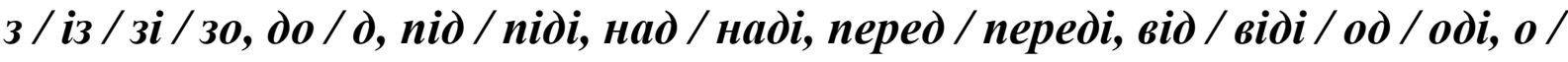
об стилістичне редагування, усування найпоширеніших помилок: небажаний збіг голосних / приголосних, випадковий звуковий повтор у використанні слів з однаковими закінченнями, небажана епіфора у використанні інфінітивів, повтор службових слів, омонімічність прийменника i префікса, недоречна рима i невиправдана ритмізація висловлювання); здійснення стилістичного аналізу текстів, уміння визначати функцію звука в мовленні (знаходити приклади звукової анафори, епіфори та ін., визначати їх стилістичні функції, здійснювати аудіозапис власного мовлення й аналізувати його, визначати, за допомогою яких засобів твориться звуковий фон тексту, знаходити i пояснювати звукоповтори як особливу інструментовку тексту).

На особливу увагу у процесі формування фоностилістичних умінь i навичок заслуговує метод вправ, оскільки «вони допомагають глибше зрозуміти закономірності розвитку рідної мови, пізнати ії красу і багатство i навчитися нею користуватися» [3, с. 330]. Багато завдань розробляються на основі спостереження над природою звуків, роботою органів мовлення, сполучуваністю звуків і їх функцією в мові. Система вправ 3 фонетики також передбачає і творчі завдання, які сприяють формуванню в учнів правильної дикції, виразного читання, правильного наголошування, виділення логічного наголосу тощо. Послуговуючись сучасними досягненнями мовознавства (учення про фонетичну систему мови, комунікативну та когнітивну лінгвістику), педагогіки (компетентнісний підхід) та лінгводидактики (формування мовної, мовленнєвої та комунікативної компетенцій), 3. Бакум, виокремлює:

1) фонетико-лінгвістичні вправи - спрямовані на формування лінгвістичної компетенції учнів і передбачають: знання про фонетичну систему української мови (система знань про лінійний та нелінійний рівні фонетики, фонологію, відомості про методи артикуляційних та акустичних досліджень, довідки про видатних фонетистів, елементи історичних 
коментарів фонетичних явищ); мовні вміння і навички (розпізнавальні, класифікаційні, аналітичні, синтетичні);

2) фонетико-мовленнєві вправи пропонуються для формування мовленнєвої компетенції учнів на етапі узагальнення і систематизації знань iз фонетики: знання норм усного та писемного мовлення, функційностилістичне використання фонетичних засобів; мовленнєві вміння та навички: орфоепічні, фоностилістичні, правописні;

3) фонетико-комунікативні вправи сприяють формуванню комунікативної компетенції учнів і грунтуються на усвідомленні мовленнєвознавчих понять, удосконаленні мовленнєвих умінь та навичок (продуктивних: говоріння, письмо; рецептивних: читання, аудіювання), удосконаленні вмінь, навичок спілкування, адекватних до сфер ситуації спілкування [2, с. 217].

Для того щоб учні зрозуміли завдання функціональних стилів, провідні риси й особливості їх вираження, оволоділи умінням вживати стилістичні засоби у власному мовленні, методистами запропоновано систему стилістичних вправ, побудованих на принципах, які відображають зміст, місце, структуру вправ у процесі застосування, а саме: 1) змістовність тексту; 2) здійснення міжпредметних зв’язків і порівняння текстів різних стилів; 3) відповідність змісту тексту вправ матеріалові програмових розділів; 4) перспективність, наступність і систематичність вправ; 5) диференційований підхід до знань учнів у доборі вправ; 6) підпорядкування змісту вправ роботі над типовими помилками в мовленні учнів; 7) добір видів вправ залежно від методів та прийомів їх реалізації [3, с. 330]. Урахування названих принципів забезпечує максимальну ефективність у доборі вчителем вправ, оскільки різнобічний підхід оптимізує процес навчання.

У сучасній методиці навчання стилістики подано таку класифікацію вправ: лексико-стилістичні, фонетико-стилістичні, граматико-стилістичні. Щодо формування стилістичних умінь, то воно має проходити у три етапи: 1) ознайомлення зі стилями; 2) аналіз текстів різних стилів; 3) редагування чужих і власних висловлювань, трансформація, складання невеликих текстів.

Фонетико-стилістичні вправи М. Пентилюк поділяє на усні (виразне читання текстів різних стилів, вправи на правильне наголошування слів, інтонування речень, на виправлення порушень милозвучності української мови) та письмові (запис виправлених текстів, редагування речень 3 недоцільним нагромадженням однакових звуків, складів, добір фонетичних варіантів та конструювання з ними речень, спостереження над евфонічними чергуваннями звуків) [3, с. 203].

Така робота викликає в учнів інтерес до виучуваного матеріалу, виховує в них чуття мови, бережливе ставлення до мови. Важливо визначити місце застосування стилістичних вправ, оскільки стилістика вивчається поруч із фонетикою, лексикою та граматикою. Відповідно до 
цього методисти виокремлюють супровідні вправи (доповнюють, деталізують виучувану лексичну, фонетичну або граматичну тему зі стилістичного боку й служать джерелом інформації), спеціальні вправи (розкривають конкретні стилістичні ознаки мовних явищ і виконуються під час вивчення суто стилістичних тем) та вправи на закріплення i поглиблення знань і навичок (тренувальні вправи) [3, с. 332].

Опорною класифікацією фоностилістичних вправ для нашого дослідження стала класифікація 3. Бакум, яка на основі лінгвістичних розробок пропонує у шкільному курсі фоностилістики виокремити такі вправи: евфонічні (побудовані на законах милозвучності), статистичні (в основу яких покладено математичний принцип підрахунку наголошених / ненаголошених, голосних / приголосних, залежно від частоти тих чи тих звуків учні роблять певні висновки), звукоповторювальні (використовуються для глибшого розуміння учнями засобів фоностилістики: алітерація, асонанс, епіфора, анафора та ін.), звуковідтворювальні і звуконаслідувальні (показують вплив окремих звуків або звукосполучень на зміст тексту та сприйняття його читачем) [1, с. 2]. Окрім того, пропонуємо додати вправи інтонаційні, фоностилістичного редагування, фоностилістичного аналізу. Так, виконуючи інтонаційні вправи, учні з'ясовуватимуть, за допомогою яких фонетичних засобів інтонація організовує мовлення, як мелодика, ритм, темп, інтенсивність, тембр та інші просодичні елементи впливають на емоційну забарвленість висловлювання, яким чином співвідносяться інтонація і стиль.

Вправа. Прочитайте вірші «Ви знаєте як липа шелестить» П. Тичини i «Рінь» О. Ольжича. Порівняйте темп і тембр обох творів. 3'ясуйте, яким чином темп і тембр впливають на емоційне забарвлення.

Уміння i навички фоностилістично редагувати текст формуватимуться через удосконалення стилю сказаного і написаного.

Вправа. Прочитайте речення. Знайдіть і виправте помилки в їх звуковому оформленні. У чому, на вашу думку, причина таких порушень? Запишіть правильно.

1. Переконавиись в справедливості батькових слів, Андрійко вибачивсь за свій вчинок. 2. За книгами ми стрінемо світання. 3. У своїй роботі учень допустив чимало помилок. 4. Чого город заріс бур'яном? 5. Небо, здавалось, розкололось від грому. 6. I місящь по небу котивсь підковою.

За допомогою стилістичного аналізу учні визначатимуть функцію звука в мовленні, знаходитимуть приклади звукової анафори, епіфори, визначатимуть їх стилістичні функції та ін..

Вправа. Підрахуйте, які приголосні звуки найчастіше вживаються у поданих творах П. Тичини «Я сказав тобі лиш слово», «Похорон друга» (уривок). Зробіть порівняльний аналіз. Як відбивається частота вживання 
певних звуків на загальному емоційному навантаженні твору? Які фонетичні засоби використав автор?

Отже, правильно дібрана система вправ сприяє ефективному формуванню фоностилістичних умінь i навичок, допомагає усунути в учнівському мовленні найпоширеніші помилки (збіг голосних / приголосних, випадковий звуковий повтор у використанні слів 3 однаковими закінченнями, небажана епіфора у використанні інфінітивів, повтор службових слів, омонімічність прийменника і префікса, недоречна рима i невиправдана ритмізація висловлювання тощо), дотримуватися правил евфонії. Навчання фонетики на стилістичній основі через систему вправ збагачує мовний арсенал, якісно підвищує мовленнєвий рівень, надає мовленню школярів нового експресивного забарвлення, формує вміння доцільно послуговуватися фонетичними засобами у відповідній мовленнєвій ситуації, ураховуючи мету мовлення, сприяє глибшому розумінню природи звука, його особливостей.

\section{Література}

1. Бакум 3. Елементи фоностилістики на уроках словесності / З. Бакум, Л. Бойко // Українська мова і література в школі. - 2006. - №2. - С. 2.

2. Бакум 3. П. Теоретико-методично засади навчання фонетики української мови в гімназії / 3. П. Бакум. - Кривий Ріг : Видавничий дім, 2008. - 337 с.

3. Методика навчання української мови в середніх освітніх закладах / М. І. Пентилюк, С. О. Караман, О. В. Караман, О. М. Горошкіна, 3. П. Бакум, та ін.; за ред. М.І. Пентилюк. - К. : Ленвіт, 2005. $-400 \mathrm{c}$ 